\title{
CORE ETHICAL VALUES PENDIDIKAN KARAKTER BERBASIS NILAI-NILAI ISLAM
}

\author{
Ahmad Husni Hamim, \\ UIN Sunan Gunung Djati Bandung \\ e-mail: ahmadhusni030467@gmail.com \\ Ani Rindiani \\ UIN Sunan Gunung Djati Bandung \\ e-mail: ani.rindiani288@gmail.com \\ Aan Hasanah \\ UIN Sunan Gunung Djati Bandung \\ e-mail:aanhasanah@uinsgd.ac.id \\ Bambang Samsul Arifin \\ UIN Sunan Gunung Djati Bandung \\ e-mail: bambangsamsularifin@uinsgd.ac.id
}

\begin{abstract}
Abstrak
Tulisan ini bertujuan untuk mengungkap nilai-nilai yang terkandung di dalam ajaran Islam yang bermuatan karakter. Islam adalah agama yang kaya akan nilai. Islam juga dijadikan basis rujukan dalam pendidikan karakter. Maka dapat dikatakan bahwa ketika umat Islam patuh dan taat terhadap ajarannya maka umat Islam tersebut adalah umat yang berkarakter, Masyarakat Muslim yang berkarakter adalah masyarakat taat agama yang menjadikan dunia seagai alat untuk mengumpulkan perbekalan akhirat. Pendidikan karakter pada umumnya memiliki tujuan besar yaitu mencapai akhlaqul karimah yang bersumber keada Al-Qur'an dan Hadits. Dalam pendidikan karakter berbasis Al-Qur'an dan Hadist, materi pendidikan secara garis besar dapat dikelompokkan dalam tiga dimensi nilai akhlah yaitu akhlak terhadap Allah Swt. Akhlak terhadap sesama manusia, akhlak terhadap alam semesta. Beberapa karakter utama yang melandasi karakter-karakter baik lainnya yang terdapat dalam Al-Qur'an yaitu : a) tabah dan pantang menyerah, didalamnya meliputi sabar, baik sabar scara pasif maupun sabar secara aktif, b) konsisten (istiqomah) yang konsekwensinya tidak mengikuti hawa nafsu, baik yang muncul dalam dirinya, maupun keinginan buruk orang, c) Integritas yang dibangun dari disiplin diri, disiplin untuk jujur, adil sebagaimana mestinya di setiap situasi, d) profesionalisme yang melhirkan mentalitas mutu, mentalitas altruistik, mentalitas pembelajar, dan mentalitas etis.
\end{abstract}

Kata Kunci : Pendidikan Karakter; Etika; Nilai Nilai Islam;

\section{Abstract}

This paper aims to reveal the values contained in the teachings of Islam that are character-laden. Islam is a religion rich in value. Islam is also used as a reference base in character education. So it can be said that when Muslims obey and obey the teachings then the Muslims are people of character, Muslim people who have character is a religiously obedient society that makes the world as a tool to collect supplies of the hereafter. Character education in general has a big goal that is to achieve akhlaqul karimah sourced from the Qur'an and Hadith. In character education based on 
the Qur'an and Hadith, educational materials can be broadly grouped in three dimensions of akhlah value, namely morality towards Allah Almighty. Some of the main characters that underlie other good characters contained in the Qur'an are: a) steadfast and unyielding, including patience, both passive and actively patient, $b$ ) consistent (istiqomah) whose consequences do not follow the passions, both that appear in him, as well as the bad desires of people, c) Integrity built from selfdiscipline, discipline to be honest, fair as it should be in every situation, d) professionalism that fosters quality mentality, altruistic mentality, learner mentality, and ethical mentality.

\section{Keywords : Character Education; Ethics; Islamic Value}

\section{PENDAHULUAN}

Pendidikan karakter telah menjadi polemik di berbagai negara. Pandangan pro dan kontra mewarnai diskursus pendidikan karakter sejak lama. Sejatinya, pendidikan karakter merupakan bagian esensial yang menjadi tugas Madrasah / Sekolah, tetapi selama ini kurang perhatian. Seyogyanya sekolah tidak hanya berkewajiban meningkatkan pencapaian akademis, tetapi juga bertanggung jawab dalam membentuk karakter peserta didik. Capaian akademis dan pembentukan karakter yang baik merupakan dua misi integral yang harus mendapat perhatian sekolah. Namun tuntutan ekonomi dan politik pendidikan menyebabkan penekanan pada pencapaian akademis mengalahkan idealitas peran sekolah dalam pembentukan karakter (Zubaedi, 2013:14).

Pendidikan karakter bukanlah sebuah gagasan yang baru. Sepanjang sejarah, di negara-negara di seluruh dunia, pendidikan karakter memiliki dua tujuan besar; membantu anak-anak menjadi pintar dan membantu mereka menjadi baik. Pintar dan baik tidaklah sama. Sejak zaman Plato masyarakat yang bijak telah menjadikan pendidikan karakter sebagai tujuan sekolah. Mereka memberikan pendidikan karakter yang dibarengkan dengan pendidikan intelektual, kesusilaan dan literasi, serta budi pekerti dan pengetahuan. Mereka mencoba membentuk sebuah masyarakat yang menggunakan kecerdasan untuk kemaslahatan, dan mencoba membangun dunia lebih baik (Thomas Lickona, 2014:6).

Pendidikan karakter mengalami kemunduran mengakibatkan kemerosotan moral. Di antara kemerosotan moral yang terjadi adalah ; meningkatnya pergaulan seks bebas, tingginya angka kekerasan anak-anak dan remaja, kejahatan terhadap teman, pencurian remaja, kebiasaan menyontek, penyalahgunaan obat-obatan, pornografi, perkosaan, perampasan, dan perusakan hak milik orang lain menjadi masalah sosial yang hingga saat ini bahwa seluruh pengetahuan moral dan agama yang didapatkan dibangku sekolah ternyata tidak atau belum dapat diatasi secara tuntas.

Kondisi krisis dan dekadensi moral ini menandakan berdampak terhadap perubahan tingkah laku siswa. Banyak orang berpandangan bahwa kondisi demikian diduga berawal dari proses pembelajaran yang cenderung mengajarkan pendidikan moral sebatas teks dan kurang mempersiapkan siswa untuk menyikapi dan menghadapi kehidupan yang kontradiktif. Atas kondisi demikian pendidikan karakter mulai mendapat perhatian dari banyak pihak. Pendidikan karakter di Indonesia pertama kali dicetuskan oleh Ratna Megawangi, alumnus IPB yang concern terhadap dunia pendidikan anak dan perempuan. Melalui konsep pendidikan holistik berbasis karakter, Mengawangi mengedepankan sembilan karakter yang ingin dibangun. Istilah pendidikan karakter ini kembali menguat ketika Menteri Pendidikan dan Kebudayaan RI, Muhammad Nuh, dalam pidatonya pada Hari Pendidikan Nasional tahun 2011 menekankan pentingnya pendidikan karakter sebagai upaya pembangunan karakter bangsa (Amri Syafri, 2014:34). Bagaimana dengan pendidikan karakter berbasis Nilai-Nilai Islam. Landasan pendidikan karakter berbasis Nilai-Nilai Islam

\section{Al-Hasanah : Jurnal Pendidikan Agama Islam}

Volume 6, Nomor 1, Januari - Juni 2021 
dalam al-Qur'an terdapat dalam QS. AnNisa' ayat 9 :

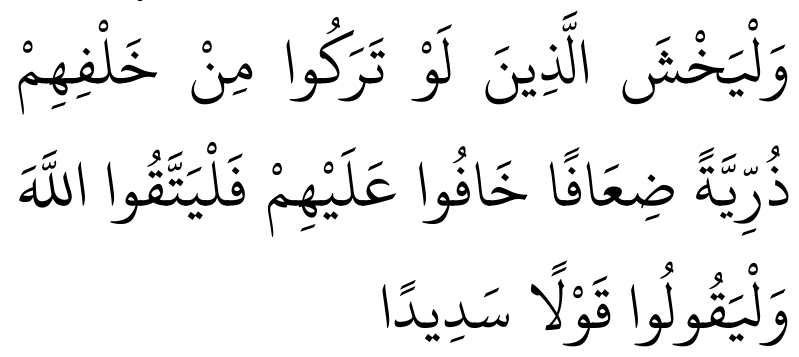

"Dan hendaklah takut kepada Allah orang-orang yang seandainya meninggalkan dibelakang mereka anakanak yang lemah, yang mereka khawatir terhadap (kesejahteraan) mereka. Oleh sebab itu hendaklah mereka bertakwa kepada Allah dan hendaklah mereka mengucapkan perkataan yang benar."

Dalam ayat tersebut Allah mengharuskan setiap umat tidak meninggalkan dibelakang mereka generasi yang lemah, tak berdaya dan tak memiliki daya saing dalam kompetisi kehidupan. Ayat ini juga dapat diartikan secara umum bahwa ada pesan al Qur'an kepada setiap Muslim untuk berupaya sekeras-kerasnya agar generasi sesudahnya merupakan generasi yang tangguh melebihi para pendahulunya (Kementerian Agama RI, 2010:11-12).

Dalam al-Qur'an kesempurnaan manusia tidak hanya terletak pada dimensi jasadiah semata, akan tetapi juga melalui dimensi rohania, maka manusia akan senantiasa bertahan pada posisinya sebagai makhluk terbaik. Pengembangan pada sisi jasmaniah semata hanya akan menjatuhkan manusia ke tempat yang paling rendah (asfala safilin). Pengembangan dimensi rohaniah akan melahirkan akhlak terpuji. Makalah ini akan mencoba memaparkan bagaimana pendidikan karakter Berbasis Nilai-Nilai Islam.

\section{METODOLOGI}

Metode penelitian yang digunakan dalam penelitian ini adalah penelitian kualitatif, dengan pendekatan deskriptif analitis. Penelitian kualitatif adalah proses pemecahan suatu masalah yang berhubungan dengan manusia dengan bertujuan untuk memahami fenomena yang terjadi, dengan latar belakang sosial maupun kultural. Penelitian ini dilakukan dengan tidak menganalisa angka dan melaporkan deskripsi hasil penelitian secara detail (Pertiwi \& Weganofa, 2015: 19).

Pada pendekatan kualitatif arah dan fokus suatu penelitian adalah membangun teori dari data atau fakta, mengembangkan sintesa interaksi dan teori-teori yang dibangun dari fakta-fakta mendasar (grounded) mengembangkan pengertian, dan sebagainya yang berarti tiap langkah mengutamakan proses apa adanya dan tanpa dibatasi normanorma, rumus, dan yang lainnya (Musianto, 2002). Tujuan utama penelitian kualitatif yaitu untuk menangkap arti (meaning/ understanding) yang terdalam atas suatu kejadian, gejala, fakta atau masalah tertentu dan bukan untuk mempelajari atau membuktikan adanya hubungan sebab akibat dari suatu masalah atau peristiwa (Raco, 2010:106).

\section{HASIL DAN PEMBAHASAN}

\section{Karakter}

Secara harfiah istilah karakter berasal dari bahasa Inggris "character" yang berarti watak, karakter, atau sifat (John M Echols dan Hasan Shadily, 1979:107). Dalam KBBI watak diartikan sebagai sifat batin manusia yang mempengaruhi segenap pikiran dan perbuatannya, atau berarti tabiat, dan budi pekerti (Tim Penyusun, 2008:1811). Karakter adalah tabiat, sifat-sifat kejiwaan, akhlak, atau budi pekerti yang membedakan seseorang dengan yang lain. Menurut Zubaidi karakter adalah:

"distinctive trait, distinctive quality, moral strength, the pattern of behavior found in an individual or group." "Character determines someone's private thought and someoen's perfect done. Good character is the inward 
motivation to do what is rigth, according to the highest standard of behavior in every situation. "Character is the sum of all the qualities that make you who you are. It's your values, your thoughts, your words, and your action". Karakter merupakan serangkaian sikap, perilaku, motivasi, dan keterampilan untuk melakukan hal yang terbaik. Karakter adalah keseluruhan nilai-nilai, pemikiran, perkataan, dan perilaku atau perbuatan yang telah membentuk diri seseorang. Karakter merupakan jati diri, kepribadian, dan watak yang melekat pada diri seseorang. Sebagai aspek kepribadian, karakter merupakan cerminan dari kepribadian secara utuh dari mentalitas, sikap, dan perilaku seseorang (Zubaedi, 2013:9).

Wynne mengatakan karakter berasal dari bahasa Yunani yang berarti "to mark" (menandai) atau memfokuskan bagaimana mengaplikasikan nilai kebaikan dalam bentuk tindakan atau tingkah laku. Oleh sebab itu orang yang berperilaku tidak jujur, kejam, atau rakus dikatakan sebagai orang yang berkarakter jelek, sementara orang yang berperilaku jujur, suka menolong dikatakan sebagai orang yang berkarakter mulia (E Mulyasa, 2011:3). Istilah karakter erat kaitannya dengan kepribadian (personality) seseorang. Seseorang bisa disebut orang yang berkarakter (a person of character) apabila perilakunya sesuai dengan kaidah moral.

Menurut Joel Kuperman, karakter bermakna "instrument for making and graving, impress, stamp, distinctive mark, distinctive nature." Berkowtiz mengartikan karakter sebagai "an individual's set of psychological characteristic that affect person's ability and inclination to function morally." Karakter merupakan ciri yang melekat pada seseorang. Karakter menjadi tanda identifikasi. Wilhelm menyatakan "character can be measured corresponding to the individual's compliance to a behavioral standard or the individual's compliance to a set moral code." Karakter merepresentasikan identitas seseorang yang menunjukkan ketundukannya pada aturan atau standar moral dan termanifestasikan dalam tindakan.

Karakter yang baik: filosof Yunani Aristoteles mendefinisikan karakter yang baik sebagai hidup dengan tingkah laku yang benar. Tingkah laku benar dalam hal berhubungan dengan orang lain dan berhubungan dengan diri sendiri. Karakter terbentuk dari tiga bagian yang saling berkaitan; pengetahuan moral (moral knowing), perasaan moral (moral feeling), dan perilaku moral (moral behavior). Karakter yang baik terdiri atas mengetahui kebaikan (knowing the good), menginginkan kebaikan (desiring the good), dan melakukan kebaikan (doing the good). Dalam hal ini diperlukan pembiasaan dalam pemikiran (habits of the mind), pembiasaan dalam hati (habits of heart), dan pembiasan dalam tindakan (habits of the action) (Thomas Lickona, 2014). Berdasarkan pendapat di atas dapat dikatakan bahwa karakter yang baik harus didukung oleh pengetahuan tentang kebaikan, keinginan untuk berbuat baik, dan kemampuan untuk melakukan perbuatan baik.

Karakter seseorang berkembang berdasarkan potensi yang dibawa sejak lahir atau yang dikenal sebagai karakter dasar yang bersifat biologis. Menurut Ki Hajar Dewantara, aktualisasi karakter dalam bentuk perilaku sebagai hasil perpaduan antara karakter biologis dan hasil interaksi dengan lingkungannya. Karakter dapat dibentuk melalui pendidikan karena pendidikan merupakan alat yang paling efektif untuk menyadarkan individu dalam jati diri kemanusiaannya. Dengan pendidikan akan dihasilkan kualitas manusia yang memiliki kehalusan budi dan jiwa, memiliki kecemerlangan pikiran, kecekatan raga, dan memiliki kesadaran penciptaan dirinya. Dibanding faktor lain, pendidikan memberikan dampak dua atau tiga kali lebih kuat dalam pembentukan kualitas manusia. Dalam Al-Qur'an konsep karakter menggunakan term "akhlak" sebagaimana yang terdapat dalam hadits dan ayat sebagai berikut: 


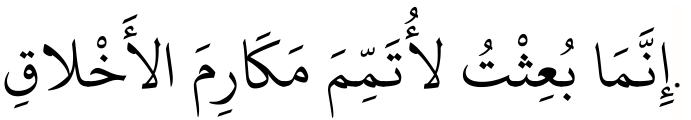

"Sesungguhnya aku diutus untuk menyempurnakan akhlak yang sholeh". (HR Bukhari dalam shahih Bukhari kitab adab, Baihaqi dalam kitab syu'bil Iman dan Hakim).

Firman Allah dalam Surah al-Qalam ayat 4 menyatakan :

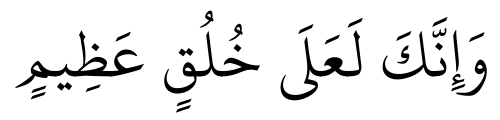

"Dan sesungguhnya kamu benar-benar berbudi pekerti yang agung". (QS. alQalam ayat 4).

Akhlak menurut bahasa adalah bentuk jamak dari "khuluq" yang berarti sebuah kebiasaan dan perbuatan yang terus diulang. Huruf lam mengandung arti al-dien (kepercayaan), al-thab'u (karakter), dan alsijiyyat (watak) yang intinya bermakna perasaan jiwa seseorang, naluri, sifat, dan artiarti khusus yang ditampilkan dalam perilaku yang nyata, baik atau buruk, melahirkan penghargaan atau celaan. Hampir semua kamus bahasa Arab sepakat mendefinisikan al-khuluq sebagai sebuah kondisi perasaan jiwa yang kuat untuk menciptakan tindakantindakan tanpa membutuhkan pemikiran atau ide (Amri Rahman dan Dulsukmi Kasim, 2014). Ahmad Amin mendefinisikan akhlak sebagai kehendak yang dibiasakan. Artinya, kehendak itu bila membiasakan sesuatu, kebiasaan itu dinamakan akhlak (Zahrudin Ar dan Hasanuddin Sinaga, 2004:4).

Berdasarkan pendapat Ahmad Amin di atas, kehendak merupakan ketentuan dari beberapa keinginan manusia setelah bimbang. Sedangkan kebiasaan merupakan perbuatan yang diulang-ulang sehingga mudah melakukannya. Masing-masing dari kehendak dan kebiasaan ini mempunyai kekuatan, dan gabungan dari kehendak dan kebiasaan ini menimbulkan kekuatan yang lebih besar. Kekuatan yang besar inilah yang disebut akhlak. Apabila kebiasaan menghasilkan suatu perbuatan baik disebut akhlakul karimah, bila menghasilkan perbuatan buruk disebut akhlakul mazmumah.

Menurut Philip K Hitti ada tiga cara pandang yang berbeda di kalangan Islam melihat persoalan akhlak. Pertama, melihat akhlak dalam hubungannya dengan tertib sopan sehari-hari (popular philosophy of morality). Kedua, melihat akhlak dalam hubungannya dengan pengetahuan (philosophical). Ketiga, melihat akhlak dalam hubungannya dengan masalah kejiwaan (mystical psychological). Secara sederhana dapat dikatakan dalam membahas tingkah laku manusia menggunakan pendekatan teoritis dan praktis. Pendekatan yang bersifat teoritis merupakan bagian dari usaha rasionalisasi terhadap tingkah laku manusia berupa pikiran-pikiran logis tentang sesuatu yang harus diperbuat oleh manusia. Sedangkan pendekatan praktis menunjuk secara langsung tingkah laku manusia. Tingkah laku ini bisa dilihat sebagai hasil pikiran logis manusia ketika menyadari kehidupan sosialnya. Misalnya mana perbuatan yang harus dilakukan, mana perbuatan yang mesti ditinggalkan, mana perbuatan yang baik, serta mana perbuatan yang buruk (Ajat Sudrajat, 2012).

Namun demikian haruslah dipahami bahwa pembicaraan mengenai akhlak tidak semata-mata merujuk kepada masalah kesopanan belaka, melainkan merujuk kepada pengertian yang lebih mendasar berkaitan dengan pandangan hidup tentang baik dan buruk, benar dan salah. Oleh karena itu, menurut Quraish Shihab, akhlak dalam agama Islam tidak dapat disamakan dengan etika atau moral jika pengertiannya hanya semata merujuk kepada sopan santun di antara manusia serta hanya berkaitan dengan tingkah laku lahiriah. Akhlak dalam Islam memiliki makna yang lebih luas yang mencakup beberapa hal yang tidak merupakan sifat lahiriah. Akhlak Islam berkaitan dengan sikap batin maupun pikiran. Akhlak Islam juga memiliki cakupan yang lebih luas karena tidak semata mengatur hubungan manusia denga manusia. Akhlak Islam mencakup hubungan manusia dengan Allah, hubungan 
manusia dengan manusia, serta hubungan manusia dengan makhluk lainnya (M Quraish Shihab, 1996:261).

Akhlak merupakan satu kesatuan utuh dari ajaran Islam, maka akhlak dalam Islam berdasarkan kaidah-kaidahnya tentang baikburuk, benar-salah, bersumberkan kepada ajaran Allah. Tolok ukur kelakuan baik dan buruk mestilah merujuk kepada ketentuan Allah. Diyakini sepenuhnya bahwa apa yang dinilai baik oleh Allah pasti baik dalam esensinya. Demikian pula sebaliknya, tidak mungkin Allah menilai kebohongan sebagai kelakuan baik, karena kebohongan esensinya adalah buruk.

Dalam al-Qur'an, karakter yang baik merupakan interaksi seluruh totalitas manusia, bukan nalar saja, tapi gabungan antara nalar dengan kesadaran moral dan kesucian jiwa. Karena itu karakter yang terpuji adalah hasil internalisasi nilai-nilai agama dan moral pada diri seseorang yang ditandai oleh sikap dan perilaku positif. Beberapa karakter utama yang melandasi karakter-karakter baik lainnya yang terdapat dalam al-Qur'an adalah ; a) tabah dan pantang menyerah di dalamnya meliputi sabar, baik sabar secara pasif maupun sabar secara aktif, b) konsisten (istiqamah) yang konsekuensinya tidak mengikuti hawa nafsu, baik yang muncul dari dirinya maupun keinginan buruk orang lain, c) integritas yang dibangun dari disiplin diri, disiplin untuk jujur, adil sebagaimana mestinya di setiap situasi, d) profesionalime yang melahirkan mentalitas mutu, mentalitas altruistik, mentalitas pembelajar, dan mentalitas etis (Kementerian Agama RI, 2016:134-162).

\section{Pendidikan Karakter}

Pendidikan karakter diartikan sebagai "the delibrete us of all dimensions of school life to foster optimal character development" (Suparlan, 2010), (usaha secara sengaja dari seluruh kehidupan dimensi sekolah untuk membantu pengembangan karakter dengan optimal). Hal ini berarti untuk mendukung perkembangan karakter peserta didik harus melibatkan seluruh komponen di sekolah baik dari aspek isi kurikulum (the contet of the curriculum), proses pembelajaran (the procces of instruction), kualitas hubungan (the quality of relationship), penanganan mata pelajaran (the handling of discipline), serta etos seluruh lingkungan sekolah.

Pendidikan karakter juga didefinisikan "the deliberate effort to cultivate virtue that is objectively good human qualities that are good for the individual person and good for the whole society" (Suparlan, 2010), (usaha sengaja untuk mewujudkan kebajikan yaitu kualitas kemanusiaan yang baik secara objektif, bukan hanya untuk individu perseorangan, tetapi juga baik untuk masyarakat secara keseluruhan).

Menurut David Elkind \& Freddy Sweet, "character education is the deliberate effort to help people understand, care about, and act upon core ethicall value" (Suparlan, 2010), (pendidikan karakter adalah usaha sengaja untuk membantu manusia memahami, peduli tentang, dan melaksanakan nilai-nilai etika inti).

Lebih lanjut David Elkind \& Freddy Sweet mengatakan, "when we think about the kind of character we want for our children, it is clear that we want them to be able to judge what is right, care deeply about what is right, and than do what they believe to be right, event in the first pressure from without and temptation from within" (Suparlan, 2010), (ketika berpikir tentang jenis karakter yang dinginkan bagi anak-anak, maka jelas bahwa kita mengharapkan mereka mampu menilai apakah kebenaran, peduli secara sungguhsungguh terhadap kebenaran, dan kemudian mengerjakan apa yang diyakini sebagai kebenaran, bahkan ketika menghadapi tekanan dari luar dan upaya dari dalam).

Williams \& Schnaps mendefinisikan, "character eduation is any deleberate approach by which school personnel, often in conjuction with parents and community members, help children and youth become caring, principled and responsible", (Suparlan, 2010), (pendidikan karakter merupakan berbagai usaha yang dilakukan oleh para personel sekolah, bersama-sama dengan orang tua dan anggota masyarakat,

\section{Al-Hasanah : Jurnal Pendidikan Agama Islam}

Volume 6, Nomor 1, Januari - Juni 2021 
untuk membantu anak-anak dan remaja menjadi atau memiliki sifat peduli, berpendirian, dan bertanggung jawab).

Dalam nuansa bimbingan dan konseling menurut American School Counselor menyatakan tujuan pendidikan karakter, "assist students in becaming positive and selfdircted in their lives and education and in striving toward future goals (Muhammad Nur Wangid, 2010:124-125),"(membantu siswa menjadi lebih positif dan mampu mengarahkan diri dalam pendidikan dan kehidupan, dan berusaha keras dalam pencapaian tujuan masa depannya).

Dari beberapa pendapat di atas dapat dipahami bahwa pendidikan karakter merupakan upaya penanaman kecerdasan dalam berpikir, penghayatan dalam bentuk sikap, dan pengamalan dalam bentuk perilaku yang sesuai dengan nilai-nilai luhur yang menjadi jati dirinya. Diwujudkan dalam interaksi dengan Tuhannya, diri sendiri, antarsesama, dan lingkungannya. Nilai-nilai luhur tersebut antara lain; kejujuran, kemandirian, sopan santun, kemuliaan sosial, kecerdasan berpikir dan berpikir logis. Penanaman pendidikan karakter tidak bisa hanya sekedar mentransfer ilmu pengetahuan atau melatih suatu keterampilan tertentu. Penanaman pendidikan karakter perlu proses, contoh teladan, dan pembiasaan atau pembudayaan dalam lingkungan peserta didik di lingkungan sekolah, keluarga, maupun lingkungan masyarakat.

Dalam Al-Qur'an pendidikan karakter bertujuan untuk :

1. Mengeluarkan dan membebaskan manusia dari kehidupan yang gelap (tersesat) kepada kehidupan yang terang (lurus) (QS. Al-Ahzab ayat 43).

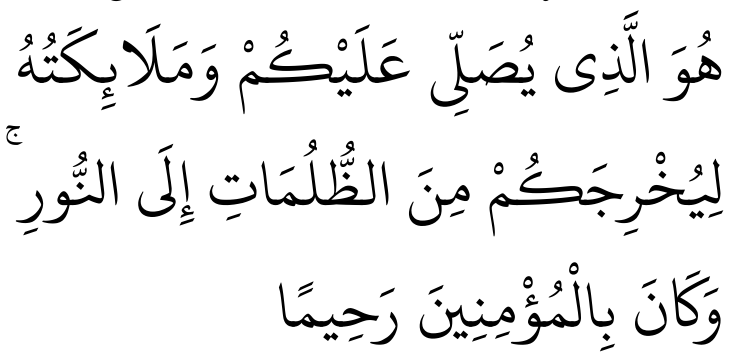

"Dialah yang memberi rahmat kepadamu dan para malaikat-Nya (memohonkan ampunan untukmu), agar Dia mengeluarkan kamu dari kegelapan kepada cahaya (yang terang). Dan Dia Maha Penyayang kepada orang-orang yang beriman."

2. Menunjukkan manusia dari kehidupan yang keliru kepada kehidupan yang benar (QS. Al- Jumu'ah ayat : 2).

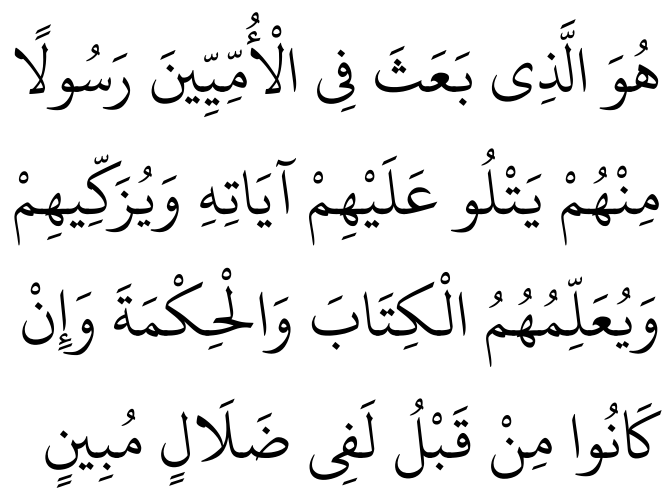

"Dialah yang mengutus kepada kaum yang buta huruf seorang Rasul di antara mereka, yang membacakan ayat-ayat-Nya kepada mereka, mensucikan mereka dan mengajarkan mereka Kitab dan Hikmah (As Sunnah). Dan sesungguhnya mereka sebelumnya benar-benar dalam kesesatan yang nyata."

3. Mendamaikan manusia yang bermusuhan menjadi bersaudara, menyelamatkan manusia yang berada di tepi jurang kehancuran, serta menjadi manusia yang selamat dunia dan akhirat (QS. ali-Imran ayat : 3) (Amri Rahman dan Dulsukmi Kasim, 2014).

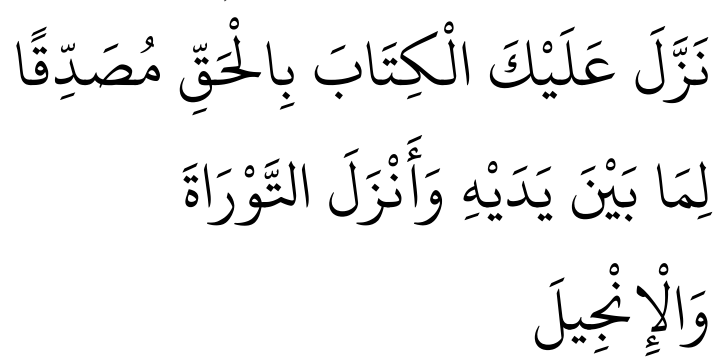

"Dia menurunkan Al Kitab (Al Quran) kepadamu dengan sebenarnya; membenarkan kitab 
yang telah diturunkan sebelumnya dan menurunkan Taurat dan Injil."

\section{Pendidikan Karakter dalam Al-Qu'ran}

Disadari bahwa karakter/akhlak/moral yang dimiliki manusia bersifat fleksibel atau luwes serta bisa diubah atau dibentuk. Karakter/akhlak/moral manusia suatu saat bisa baik tetapi pada saat lain sebaliknya menjadi jahat. Perubahan ini bergantung bagaimana proses interaksi antara potensi dan sifat alami yang dimiliki manusia dengan kondisi lingkungan, sosial budaya, pendidikan, dan alam.

Pendidikan karakter di Indonesia didasarkan pada sembilan pilar karakter dasar. Karakter dasar menjadi tujuan pendidikan karakter. Kesembilan pilar karakter dasar ini adalah ; a) cinta kepada Allah dan semesta beserta isinya, b) tanggung jawab, disiplin, dan mandiri c) jujur, d) hormat dan santun, e) kasih sayang, peduli, dan kerja sama f) percaya diri, kreatif, kerja keras, dan pantang menyerah, g) keadilan dan kepemimpinan, h) baik dan rendah hati, dan i) toleransi (Zubaedi, 2013). Sedangkan menurut Michele Borba ada tujuh nilai kebajikan yang perlu diajarkan pada anak agar anak bermoral tinggi, yaitu ; a) empati, b) hati nurani, c) kontrol diri, d) rasa hormat, e) kebaikan hati, f) toleransi, dan g) keadilan (Michele Borba, 2008:7).

Dalam pendidikan karakter berbasis AlQur'an, materi pendidikan karakter secara garis besar dapat dikelompokkan dalam tiga dimensi nilai akhlak, yaitu; akhlak terhadap Allah, akhlak terhadap sesama manusia, dan akhlak terhadap alam semesta (Zubaedi, 2013). Ruang lingkup akhlak terhadap Allah meliputi ; a) mengenal Allah, b) berhubungan dengan Allah, dan c) meminta tolong kepada Allah. Ruang lingkup akhlak terhadap manusia mencakup ; a) akhlak terhadap orang tua, b) akhlak terhadap saudara, c) akhlak terhadap tetangga, dan d) akhlak terhadap lingkungan masyarakat (M Yatimin Abdullah, 2007:221). Bagian ketiga adalah akhlak terhadap alam sekitar. Akhlak manusia terhadap alam bukan hanya semata-mata untuk kepentingan alam, tetapi jauh dari itu untuk memelihara, melestarikan, dan sekaligus untuk memakmurkan manusia. Hubungan manusia dengan alam bukan hubungan antara penakluk dengan yang ditaklukkan, tetapi hubungan kebersamaan dalam ketundukan kepada Allah. Hal ini karena kemampuan manusia dalam mengelola bukanlah akibat kekuatan yang dimiliki, tetapi akibat anugerah Allah (M Quraish Shihab, 1998:295).

Tiga dimensi akhlak di atas menjadi materi yang mengisi pendidikan karakter. Atas pemikiran tersebut, pendidikan karakter perlu memperhatikan pentingnya dimensi penanaman akhlak terpuji (akhlakul karimah). Menurut Hamka, akhlak yang terpuji berarti sifat-sifat atau tingkah laku yang sesuai dengan norma-norma atau ajaran Islam. Akhlak terpuji berisi sikap taat, baik taat secara lahiriah maupun taat secara batiniah. Taat secara lahir berarti melakukan seluruh amal ibadah yang diwajibkan Allah, termasuk berbuat baik kepada sesama manusia dan lingkungan. Beberapa perbuatan yang dikategorikan taat lahiriah adalah :

a. Taubat, dikategorikan taat lahir dilihat dari sikap dan tingkah laku seseorang. Namun sifat penyesalan merupakan taat batin.

b. Amar ma'ruf nahi mungkar, perbuatan yang dilakukan kepada manusia untuk menjalankan kebaikan dan meninggalkan kemungkaran.

c. Syukur, berterima kasih terhadap nikmat yang telah dianugerahkan Allah kepada manusia dan seluruh makhluknya (Hamka, 1981:179).

Taat batin adalah segala sifat yang baik, yang terpuji yang dilakukan oleh anggota batin (hati). Yang termasuk taat batin adalah :

a) Tawakal, yaitu berserah diri sepenuhnya kepada Allah dalam menghadapi, menanti, atau menunggu hasil pekerjaan.

b) Sabar, yaitu sabar dalam beribadah, sabar ketika ditimpa musibah, sabar terhadap kehidupan dunia, sabar terhadap maksiat, dan sabar dalam perjuangan. Dasarnya adalah keyakinan bahwa semua yang 
dihadapi adalah ujian dan cobaan dari Allah.

c) Qana'ah, yaitu merasa cukup dan rela dengan pemberian yang dianugerahkan Allah. Qana'ah meliputi menerima dengan rela apa yang ada, memohon kepada Allah tambahan yang pantas dan ikhtiar, menerima dengan sabar akan keentuan Allah, bertawakal kepada Allah, serta tidak tertarik oleh tipu daya dunia (Hamka, 1981:180).

Secara esensial pendidikan karakter perlu mengupayakan penanaman akhlak terpuji dan pengendalian bahkan pembersihan dari akhlak tercela. Menurut al-Ghazali ada dua jenis akhlak yang perlu mendapat perhatian ketika seseorang mendesain isi pendidikan karakter, yaitu akhlak yang baik (akhlakul mahmudah) dan akhlak yang buruk (akhlakul madzmumah). Akhlak mahmudah adalah segala macam tingkah laku yang baik. Adapun yang termasuk sifat-sifat mahmudah adalah ; a) al-amanah (setia, jujur, dapat dipercaya), b) as-sidqu (benar, jujur), c) al'adl (adil), d) al-'afwu (pemaaf), e) al-alifah (disenangi), f) al-wafa' (menepati janji), g) alhaya' (malu), h) ar-rifqu (lemah lembut), i) anisatun (bermuka manis) (Yatimin Abdullah, 2007:25-26).

Adapun sifat-sifat madzmumah adalah sebagai berikut : a) ananiah (egoistis), b) albaghyu (melacur), c) al-buhtan (dusta), d) alkhianah (khianat), e) az-zulmu (aniaya), f) alghibah (mengumpat), g) al-hasad (dengki), h) al-kufran (mengingkari nikmat), i) ar-riya' (ingin dipuji), j) an-namimah (adu domba) (Yatimin Abdullah, 2007:26).

Akhlak terpuji termanifestasi dalam bentuk-bentuk perilaku sebagai berikut : a) bersifat sabar, b) bersifat istiqamah, c) memelihara amanah, d) bersifat adil, e) bersifat kasih sayang, f) bersifat hemat, g) bersifat berani, h) bersifat kuat, i) bersifat malu, j) menjaga kesucian diri, k) menepati janji (Yatimin Abdullah, 2007:46).

Dengan demikian jelaslah bahwa dalam pendidikan karakter berbasis Agama dimensidimensi karakter yang dikembangkan lebih mengacu pada akhlakul karimah yang bersumber pada Al-Qur'an. Inti dari akhlakul karimah adalah bersifat taat, dan ketaatan ini tidak hanya bersifat lahiriah tetapi juga bersifat batiniah. Ketaatan lahiriah dan ketaatan batiniah akan melahirkan akhlak terpuji yang termanifestasi dalam bentukbentuk perilaku tertentu.

\section{PENUTUP}

Karakter merupakan serangkaian sikap, perilaku, motivasi, dan keterampilan untuk melakukan hal yang terbaik. Karakter yang baik harus didukung oleh pengetahuan tentang kebaikan (knowing the good), keinginan untuk berbuat baik (desiring the good), dan kemampuan untuk melakukan perbuatan baik (doing the good). Dalam alQur'an konsep karakter menggunakan term "akhlak". Akhlak adalah kehendak yang dibiasakan. Kehendak merupakan ketentuan dari beberapa keinginan manusia setelah bimbang. Sedangkan kebiasaan merupakan perbuatan yang diulang-ulang sehingga mudah melakukannya. Masing-masing dari kehendak dan kebiasaan ini mempunyai kekuatan, dan gabungan dari kehendak dan kebiasaan ini menimbulkan kekuatan yang lebih besar. Kekuatan yang besar inilah yang disebut akhlak. Apabila kebiasaan menghasilkan suatu perbuatan baik disebut akhlakul karimah. Pendidikan karakter berbasis al-Qur'an pada dasarnya dibangun melalui tiga dimensi akhlak, yaitu ; akhlak pada Allah, akhlak pada diri sendiri, serta akhlak pada sesama manusia dan lingkungan.

\section{DAFTAR PUSTAKA}

Ajat Sudrajat. (2012). Pendidikan Moral dalam Perspektif Islam . Jurnal Dinamika Pendidikan No. 1 Tahun IX Maret, 21.

Amri Rahman dan Dulsukmi Kasim. (2014). Pendidikan Karakter Berbasis al-Qur'an Upaya menciptakan Bangsa yang Berkarakter. Jurnal al-Ulum Vol. 14 No. 1 Juni, 255.

\section{Al-Hasanah : Jurnal Pendidikan Agama Islam}


Amri Syafri. (2014). Pendidikan Karakter Berbasis Al-Qur'an. Jakarta: Rajagrafindo Persada.

E Mulyasa. (2011). Manajemen Pendidikan Karakter. Jakarta: Bumi Aksara.

Hamka. (1981). Tasawuf Modern. Jakarta: Yayasan Nurul Islam.

John M Echols dan Hasan Shadily. (1979). Kamus Inggris Inonesia. Jakarta: Gramedia.

Kementerian Agama RI. (2010). Tafsir Qur'an Tematik Pendidikan, Pengembangan Karakter, dan Pengembangan Sumber Daya Manusia. Jakarta: Badan Litbang dan Diklat.

Kementerian Agama RI. (2016). Tafsir Qur'an Tematik Pendidikan, Pengembangan Karakter, dan Pengembangan Sumber Daya Manusia . Jakarta: Kemenag RI.

M Quraish Shihab. (1996). Wawasan AlQur'an. (Bandung: Mizan.

M Quraish Shihab. (1998). Membumikan AlQuran. Bandung : Mizan.

M Yatimin Abdullah. (2007). Studi Akhlak dalam Persektif Al-Qur'an. Jakarta: Amzah.

Michele Borba. (2008). Building Moral Intelligence The Seven Essensial Virtues that Teach Kids to Do The Right Thing. Jakarta: Gramdeia.
Muhammad Nur Wangid. (2010). Peran Konselor Sekolah dalam Pendidikan Karakter. Jogjakarta: UNY.

Musianto, L. S. (2002). Perbedaan Pendekatan Kuantitatif dengan

Pendekatan Kualitatif dalam Metode Penelitian. Jurnal Manajemen \& Kewirausahaan, 4(2), , 123-136.

Raco, J. R. (2010). Metode Penelitian Kualitatif Jenis, Karakteristik, dan Keunggulannya. Jakarta: Gramedia Widiasarana Indonesia.

Suparlan. (2010, Oktober 15). Pendidikan Karakter Sedemikian Pentingkah dan Apakah yang Harus Kita Lakukan. Retrieved from Suparlan.com.

Thomas Lickona. (2014). Pendidikan Karakter Panduan Lengkap Mendidik Siswa Menjadi Baik dan Pintar. Bandung: Nusa Media.

Tim Penyusun. (2008). Kamus Besar Bahasa Indonesia. Jakarta: Balai Pustaka.

Yatimin Abdullah. (2007). Studi akhlak dalam perspektif alquran. Jakarta: Amzah.

Zahrudin Ar dan Hasanuddin Sinaga. (2004). Pengantar Studi Akhlak. Jakarta: Rajawali.

Zubaedi. (2013). Disain Pendidikan Karakter Konsepsi dan Aplikasinya dalam Lembaga Pendidikan. Jakarta: Kencana. 